\title{
Pendidikan Komersial Dan Gaya Hidup
}

\section{Commercial Education And Lifestyle}

\author{
Murni Eva Marlina Rumapea* \\ Program Studi Pendidikan Antropologi \\ Fakultas Ilmu Sosial, Universitas Negeri Medan, Indonesia
}

\begin{abstract}
Abstrak
Pendidikan merupakan cara untuk mengembangkan potensi melalui proses pembelajaran yang merupakan kebutuhan bersifat mutlak untuk individu, keluarga, masyarakat, bangsa dan negara. Banyak masalah yang dihadapi di bidang pendidikan, terlebih diera globalisasi saat ini baik bersifat internal dan eksternal. Seperti wajib belajar 9 tahun dirancang pemerintah sehingga masyarakat mengalami kesulitan, bukan karena ketidakmampuan masyarakat untuk mendapatkan pendidikan yang layak. Pendidikan komersil adalah pendidikan yang berorientasi hal ekonomis bukan untuk paradigma pendidikan. Akibatnya bagi berekonomi kuat (mapan) dapat memperoleh pendidikan, sedangkan bagi ekonomi lemah hanya memperoleh pendidikan bersifat seadanya. Pendidikan sudah menjadi gaya hidup. Artinya pendidikan bukan lagi bersifat potensi/mutu tetapi sudah suatu bentuk gaya hidup (life style), tanpa memikirkan peran mendasar dari lembaga dan aktivitas pendidikan. Pendidikan dianggap hanya untuk gaya-gayaan, bersifat keren, bergengsi, dan bersifat ikut-ikutan maka memaksakan diri menjalani pendidikan. Maka dari itu pemerintah melalui Badan Pemerikasa Keuangan (BPK) dan non pemerintah melalui Lembaga Ssosial Masyarakat (LSM) melakukan pemeriksaan transaksi keuangan secara rutin terhadap semua lembaga pendidikan. Pihak ini harus berkoordinasi dengan departemen pendidikan untuk mencapai tujuan. Pihak ini harus mampu dan jujur melaporkan hal yang terjadi serta berhak melakukan evaluasi terkait kebijakan pemerintah di bidang pendidikan.
\end{abstract}

Kata Kunci: Pendidikan, Komersial, Gaya Hidup

\begin{abstract}
Education is a way to develop the potential through learning process which is an absolute necessity for individuals, families, communities, nations and countries. Many problems faced in the field of education, especially in today's globalization both internal and external. As the 9-year compulsory education is designed by the government so that people are experiencing difficulties, not because of the inability of the community to get a decent education. Commercial education is economically oriented education not for education paradigm. As a result for strong economy (well established) can get education, while for the weak economy only get education is sober. Education has become a lifestyle. This means that education is no longer a potential / quality but is a form of lifestyle (life style), without considering the fundamental role of educational institutions and activities. Education is considered only for styles, cool, prestigious, and follow-up hence self-imposed education. Therefore, the government through the Financial Auditor Agency (BPK) and non-government through the Society Social Institutions (NGOs) conduct routine financial transactions of all educational institutions. This party should coordinate with the education department to achieve its goals. This party should be able to and honestly report what happened and be entitled to conduct an evaluation related to government policy in the field of education.
\end{abstract}

Keywords: Education, Commercial, Lifestyle

How to Cite: Rumapea, M.E.M., (2017), Pendidikan Komersial dan Gaya Hidup. JPPUMA: Jurnal Ilmu Pemerintahan dan Sosial Politik UMA, 5 (2): 139-148

*Corresponding author:

E-mail: murnievarumapea@gmail.com

p-ISSN: 25491660

e-ISSN: 2550-1305 


\section{PENDAHULUAN}

Pendidikan sangat berperan penting dalam kehidupan manusia, dan tidak dapat dipisahkan dari proses kehidupan manusia. Pendidikan merupakan usaha agar manusia dapat mengembangkan potensi melalui proses pembelajaran. Pendidikan merupakan kebutuhan manusia yang bersifat mutlak untuk individu, keluarga, masyarakat, bangsa dan negara. Pendidikan sebagai salah satu wujud ruang publik dalam arti siapapun berhak mendapat tanpa perbedaan status atau derajat. Dengan arti pendidikan diselenggarakan secara adil, tidak diskriminatif dengan menjunjung hak asasi manusia

Pendidikan adalah suatu proses untuk mendapatkan ilmu pengetahuan dengan tujuan meningkatkan sumber daya dan kesejahteraan hidup manusia. Pendidikan juga merupakan suatu proses yang tidak pernah berakhir dengan alasan untuk memperoleh pendididkan tidak akan mengenal usaha. Dilain hal pendidikan banyak dipahami sebagai wahana untuk menyalurkan ilmu pengetahuan, alat pembentukan watak (karakter), dapat mengasah otak, dan media untuk meningkatkan ketrampilan kerja Wahono (2001 :2). Untuk mengetahui defenisi pendidikan dalam perspektif kebijakan ada rumusan formal dan operasional sebagaimana termaktub dalam UUD No. 20 tahun 2003 tentang Sistem Pendidikan Nasional yaitu pendidikan adalah usaha sadar dan terencana untuk mewujudkan suasana belajar dan proses pembelajaran atau pelatihan agar peserta didik (siswa) secara efektif dapat mengembangkan potensi dirinya untuk memiliki kekuatan spiritual keagamaan, pengendalian diri, kepribadian, kecerdasan, akhlak mulia serta ketrampilan yang diperlukan pada masyarakat, bangsa dan negara

Dari defenisi di atas, pendidikan merupakan pilar atau sentral utama suatu negara/bangsa. Kualitas sumber daya manusia dapat mempengaruhi kemajuan/potensi suatu negara. Jika kualitas pendidikan tinggi berarti pihakpihak terkait bertanggung jawab menjalani jalur pendidikan

Menurut Prof. H. Mahmud Yunus pendidikan adalah suatu usaha untuk mempengaruhi dan menunjang anak yang memiliki tujuan untuk meningkatkan ilmu pengetahuan, jasmani, serta akhlak hingga dapat mengantarkan anak pada tujuan cita-cita tertinggi. Pendidikan menurut Ahmad D. Marimba, adalah satu sistem tuntunan yang dikerjaan secara sadar oleh pendidik (guru) pada satu sistem perubahan jasmanai dan rohani peserta didik (siswa) dengan tujuan membentuk kepribadian unggul. Kepribadian dalam arti tidak hanya pintar secara akademis tetapi baik dalam karakter.

Ki Hajar Dewantara mengemukakan bahwa pendidikan adalah tuntutan dalam hidup tumbuhnya anak-anak yang bermaksud menuntun segala kekuatan kodrati pada anak-anak dengan tujuan agar mampu menggapai keselamatan, dan kebahagiaan setingginya.

Dari pengertian di atas, pendidikan merupakan salah satu bentuk pertolongan/bimbingan yang diberikan orang berilmu terhadap perkembangan orang lain untuk mencapai kedewasaan dengan tujuan agar peserta didik memiliki kecakapan hidup secara mandiri

Komersil adalah salah satu yang berhubungan dengan dagang/diperdagangkan. Dengan kata lain komersial adalah sejenis aktivitas jual beli. Pengertian komersil, komsersial sengaja untuk menghasilkan keuntungan dan aktivitas bagi pemilik. Dari pengertian ini bukan berarti pendidikan itu seperti penjualan barang dagangan di pasar. Hanya pendidikan itu memiliki proses waktu walaupun proses waktu bukan berdasarkan aturan. Adapun fungsi komersial adalah untuk memperoleh keuntungan, atau keuntungan secara optimal. Komersial adalah sejenis badan usaha untuk menghasilkan produk yang bermutu secara bersaing 
Dalam bidang sosial fungsi komersial adalah berhubungan dengan manfaat, badan usaha secara langsung atau tidak langsung terhadap kehidupan masyarakat, seperti bidang pendidikan. Artinya komersial dalam bidang pendidikan lebih memprioritaskan kuantitas pendidik (siswa) dengan tujuan memperoleh keuntungan secara optimal

Secara terminologi gaya hidup adalah istilah untuk menggambarkan cara atau gaya hidup seseorang, Alfred Adler (1929). Suatu gaya hidup adalah bundel karateristik atau perilaku yang menyenangkan diri seseorang dalam waktu dan tempat tertentu. Suatu gaya hidup juga termasuk dalam hubungan sosial, komsumsi, hiburan dan berpakaian. Perilaku dan gaya hidup adalah campuran kebiasaan, dan cara konvensional dalam melakukan sesuatu/bertindak. Gaya hidup juga mencerminkan sikap individu dan nilai-nilai sehingga sarana untuk menempa rasa percaya diri, dan menciptkan simbol budaya berdasarkan identitas pribadi. Tidak semua aspek gaya hidup sepenuhnya mempengaruhi lingkungan. Sistem sosial dapat membatasi gaya hidup yang diterapkan pada individu dan orang lain. Maka melalui gaya hidup tercipta suatu kesadaran diri dan identitas diri. Salah satu bidang pendidikan, banyak masyarakat mengecap pendidikan dilembaga pendidikan bergensi, memiliki nama, dan bonafit

Menurut Kotler (2002), gaya hidup adalah pola hidup seseorang yang diekspresikan dalam aktivitas, minat, dan opininya. Gaya hidup menggambarkan keseluruhan diri seseorang dalam berinteraksi dengan lingkungan. Gaya hidup menurut Susanti (dalam Nugrahani 2003) adalah perpaduan antara kebutuhan ekspresi diri dan harapan kelompok terhadap seseorang dalam bertindak berdasarkan norma yang berlaku. Dan menurut Plummer, gaya hidup adalah cara hidup individu yang diidentifikasikan bagaimana menghabiskan waktu (aktivitas), apa yang dianggap penting dalam hidup (ketertarikan), dan apa yang dipikirkan.

Dari defenisi di atas secara umum dapat diartikan gaya hidup sebagai suatu dengan bagaimana seseorang menghabiskan waktu (aktivitas), apa yang dianggap penting pada lingkungan (minat), dan apa yang dipikirkan tentang diri sendiri dan lingkungan (opini). Karena itu banyak yang diketahui jenis gaya hidup yang berkembang pada masyarakat, seperti gaya hidup hedonis, metropolis, global, dan bidang pendidikan

Dalam pembentukan gaya hidup dapat dilihat dari secara demografis dan psikologis. Faktor demografis seperti berdasarkan pendidikan, usia, tingkat penghasilan, dan jenis kelamin. Sedangkan psikologis lebih bersifat komplex karena indikator penyusunan dan karateristik konsumen. Menurut Amstrong (dalam Nugraheni 2003) gaya hidup seseorang dapat dilihat dari perilaku yang dilakukan oleh individu seperti kegiatan untuk mendapatkan barang-barang jasa termasuk proses pengambilan keputusan pada kegiatan tertentu.

Lebih lanjut dikatakannya, bahwa faktor yang mempengaruhi gaya hidup dan dapat membentuk suatu kelompok homogen, bisa berasal dari (internal) yaitu: 1) Sikap dipengaruhi oleh tradisi: kebiasaan, kebudayaan, dan lingkungan sosial, 2) Pengalaman dan pengamatan sosia: dapat membentuk pandangan terhadap suatu objek, 3) Kepribadian: konfigurasi karateristik individu dan berperilaku menentukan perbedaan perilaku tiap individu, 3) Konsep diri: sebagai inti kepribadian akan menentukan perilaku individu dalam menghadapi masalah. 4) Motif: perilaku individu muncul karena adanya motif kebutuhan untuk rasa aman, dan memenuhi prestise, 5) Persepsi: proses seseorang untuk memilih, mengatur, dan menginterpretasikan informasi terhadap suatu masalah.

Faktor eksternalnya, adalah, 1) Kelompok referensi: kelompok yang memberikan pengaruh langsung atau tidak 
langsung kepada perilaku seseorang. Perilaku terbentuk jika individu menjadi anggota (pengaruh langsung), jika tidak maka tidak mempengaruhi langsung, 2) Keluarga: pola didikan orang tua membentuk perilaku seseorang, 3) Kelas sosial: ada unsur sistem sosial dapat mempengaruhi status (kedudukan) dan peranan seseorang. Membentuk kelompok yang homogen. 4) Kebudayaan: unsur kebudayaan dapat membentuk pola perilaku yang normatif, cara pola pikir dan bertindak

\section{PEMBAHASAN}

Pendidikan merupakan cara agar seseorang dapat mengembangkan potensi atau kualitas melalui proses pembelajaran. Pada dunia pendidikan banyak masalah yang dihadapi terlebih diera globalisasi saat ini baik bersifat internal dan eksternal. Pendidikan yang merupakan salah satu hak asasi manusia, namun kenyataan tidak mencapai tujuan yang diinginkan. Seperti wajib belajar 9 tahun dirancang pemerintah, banyak masyarakat mengalani kesulitan untuk merealisasikan. Bukan karena ketidakmampuan hal itu, tetapi ketidakmampuan masyarakat untuk mendapatkan pendidikan yang layak. Banyak lembaga pendidikan terutama pendidikan negeri yang masih mahal, dan mengadakan pengutan liar. Ditambah dengan liberalisasi pendidikan menyebabkan pendidikan memiliki kemampuan beroperasional sesuai yang dikehendaki. Ketika pendidikan telah diliberalisasikan maka salah satu yang muncul adalah komersialisasi pendidikan. Artinya pendidikan dijual, dan sudah dijadikan sebuah komoditas untuk memperoleh keuntungan. Pendidikan bukan memprioritaskan kualitas tetapi sudah bersifat ekonomi atau bisnis

$$
\text { Menurut Giroux (2008:115) }
$$

komersialisasi pendidikan telah mengubah institusi pendidikan yang berbasis efisiensi ekonomi menjadi perusahaan penyedia elite masyarakat dan kuli kerja. Akibat dari komersialisasi pendidikan banyak lembaga pendidikan menganut paradigma pendidikan yang bersifat ekonomis. Komersialisasi pendidikan secara tidak langsung juga telah menciptakan jurang pemisah antara pihak pemilik modal dengan tidak pemilik modal. Hal ini seperti dinyatkan Ivan Illiah (dalam Sutanto 2005:19). "Komersialisasi pendidikan dianggap sebagai misi lembaga pendidikan moderen, mengabdi kepada pemilik modal dan bukan sebagai sarana pembebasan bagi kaum tertindas". Akibtanya pendidikan yang humanisasi tidak tercapai dalam proses pendidikan, karena adanya komersialisasi pendidikan. Menurut Satriyo Brojonegoro hanya dinikmati pihak tertentu yang memiliki modal untuk mengakses pendidikan Hartini (2011:16)

Menurut Milton Friedman dan Frederik Van Hayek (2008:115) "pendidikan komersial kedaan pendidikan yang berpegang pada masyarakat industri dan selera pasar (market society". Habibe (2005:257) "komersialisasi pendidikan telah mengantarkan pendidikan sebagai instrument untuk melahirkan buruh bagi sektor industri, bukan sebgai proses pencerdasan dan pendewasaan masyarakat". Dari pendapat diatas komersialisasi pendidikan menggambarkan keadaan pendidikan saat ini lebih mengarah kepada praktik pendidikan layaknya lembaga penghasil mesin yang menyediakan pasar industri dan diukur secara ekonomis Hartini (2011:16)

Istilah komersialisasi pendidikan menurut Agus Wibowo (dalam Hartini 2011:17) mendefenisikan yang berbeda yaitu: 1) Komersialisasi pendidikan mengacu lembaga pendidikan dengan program dan perlengkapan yang mahal. Pengertian ini pendidikan hanya dapat dinikmati oleh kelompok ekonomi elite (kuat) akibatnya menimbulkan pendeskriminasian dalam pendidikan nasional dan 2) Komersialisasi pendidikan mengacu kepada lembaga pendidikan yang hanya mementingkan uang dan gedung. Tidak mementingkan kewajiban dan hak pendidikan. Artinya komersialisasi 
pendidikan hanya menjanjikan pelayanan pendidikan, tidak sepadan dengan ekonomi yang diterima, lebih mementingkan laba.

Kedaaan ini mengaibatkan efek buruk. Hanya untuk memperoleh gelar akademik tanpa melalui proses/mutu yang ditentukan. Komersialisasi pendidikan berdampak pada mahalnya biaya pendidikan. Hal sederhana adalah dalam memasiki tahun ajaran baru, banyak orang tua mengeleluh akibat buku pelajaran. Dimana buku pelajaran tahun sebelumnya sudah tidak digunakan lagi, dengan alasan bahwa buku lama sudah tidak cocok/layak lagi dipakai sebagai acuan. Padadal orang tua membeli dengan harga relatif mahal. Kondisi ini sangat memberatkan masyarakat, karena sebagian besar masih digaris kemiskinan. Jika dicermati, materi dan pokok bahasan dalam buku tersebut sama persis tanpa ada ilmu yang baru dicantumkan

Dari uraian di atas pendidikan komersil dapat ditarik kesimpulan bahwa komersialisasi pendidikan merupakan suatu keadaan bahwa dunia pendidikan lebih berorientasi kepada hal ekonomis (keuntungan) bukan untuk paradigma pendidikan. Dalam hal ini berarti pengukuran keberhasilan pendidikan dalam proses humanisasi tidak tercapai. Akibatnya bagi berekonomi kuat (mapan) yang dapat memperoleh akses pendidikan, seperti individu yang berasal dari kelas sosial atas.

Untuk mengetahui lebih mendalam ada beberapa alasan timbulnya komersialisasi pendidikan yaitu: 1) Pemerintah kurang mampu mengelola pendidikan sebagai sektor publik dengan baik, sehingga lembaga pendidikan menjadi efisien (biaya mahal, tidak sesuai dengan biaya yang dikeluarkan), kompetitif (tidak ada motivasi bersaing meningkatkan mutu), 2) Pemerintah kurang memiliki dana untuk sektor pendidikan. Kedaan ini dapat menjadi sebuah kebenaran tetapi dapat juga menjadi sebuah kebohongan. Artinya pemerintah bukan dikatakan tidak mampu, tetapi tidak memiliki visi untuk berinteraksi dibidang pendidikan. Seperti banyak lembaga pendidikan pemerintah belum memiliki fasilitas lengkap, 3) Swastanisasi pendidikan, kapitalisme dan liberalisme menguasai bidang pendidikan.

Menurut Ritzer (2005:564) privatisasi pendidikan adalah konsekuensi logis dari Mcdonalisasi Masyarakat (mcdonalization of society) yang menjunjung prinsip kuantifikasi, efisiensi, terprediksi, dan teknologisasi dalam bidang kehidupan. Artinya pendidikan tidak lagi dipandang sebagai public good, tetapi private good yang tidak lagi disediakan pemerintah secara massal untuk menjamin harga murah. Hal ini sudah menjadi kenyataan, banyak bentuk/lembaga pendidikan muncul seadanya. Tidak berdasarkan aturan perundangan, dan tidak berdasarkan tujuan pendidikan nasional.

Dengan munculnya lembaga pendidikan ini, maka terjadi hal-hal yang tidak berdasarkan tujuan pendidikan nasional. Untuk melaksanakan penerimaan siswa/peserta didik juga bersifat seadanya, bahkan yang lebih ironis sudah terjadi diskriminasi pendidikan. Artinya terjadi pemisahan peserta didik/siswa yang mampu mengecap pendidikan pada tingkat ekonomi kuat (bergengsi) dengan ekonomi lemah. Keadaan ini berdampak pada interaksi siswa pada lingkungan siswa. Ini adalah salah satu pemicu disentegrasi bangsa, tidak ada rasa kebersamaan, kesatuan, dan solidaritas bangsa

Menurut analisa penulis munculnya komersialisai pendidikan adalah disebabkan, pertama adalah kapitalisme, yaitu para kapitalis membuka lembaga pendidikan baru dengan pelayanan prima. Para kapitalis memberi syarat mudah dan praktis untuk memasuki lembaga pendidikan tersebut. Akan tetapi tidak semua kapitalis bersifat seperti ini ada juga para kapitalis memberi syarat yang sulit. Hanya lebih bersifat dominan para kapitalis memberi syarat mudah dan praktis. Kedua adalah faktor teknologi; menggunakan sistem alat teknologi 
canggih dalam proses belajar mengajar maka masyarakat berusaha memasukinya. Walaupun keadaan keterpaksaan hanya untuk menyenangkan hati sesaat. Dalam arti bukan suatu jaminan jika menggunakan sistem teknologi canggih maka mutu/kualitas pendidikan terjamin mudahnya. Ketiga adalah Budaya, yaitu pendidikan dapat menentukan strata sosial seseorang. Semakin tinggi pendidikan seseorang, maka strata sosial dalam masyarakat meningkat, demikian sebaliknya.

Hal tersebut, sesuai pendapat Kartono (2002) menyatakan tingginya tingkat pendidikan dan taraf kebudayaan rakyat akan menjadi barometer bagi pertumbuhan bangsa dan negara yang bersangkutan. Akan tetapi bagaimana mencapai pendidikan tinggi apabila biaya pendidikan mahal. Lalu bagaimana dengan masyarakat golongan ekonomi lemah. Masyarakat Indonesia masih lebih mengagungkan gelar akademis baik di lingkungan pekerjaan dan tempat tinggal. Artinya masyarakat Indonesia masih menganut budaya degree minded. Budaya berburu gelar masih berkembang dibidang pemerintah sosial dan budaya.

Secara teoretis muncul dampak komersialisasi pendidikan baik bersifat positif atau negatif. Dampak positif adalah, 1) Semakin meningkat kompetisi/persaingan antara lembaga pendidikan demi peningkatan mutu dan fasilitas. Setiap lembaga pendidikan memberi mutu dan pelayanan terbaik (pelayanan prima), 2) Bidang Ekonomi, meningkatkan pendapatan pengajar. Pengajar lebih bersifat sejahtera, memacu pengajar untuk lebih bekerja keras dalam mencerdaskan peserta didik (siswa), 3) Bagi pemerintah dapat meringankan biaya, dengan alasan lembaga pendidikan sudah bersifat mandiri. Maka anggaran tersedia dapat digunakan bidang lain, 4) Masyarakat sudah lebih giat untuk berpartisipasi dan mencerdaskan bidang pendidikan. Artinya masyarakat berlomba untuk meningkatkan pendidikan.
Dengan kurangnya perhatian pemerintah dan unsur terkait (hukum) dapat mendistorsi swastanissi pendidikan. Pengaruh negatif komersialisasi pendidikan yaitu : 1) Terjadi Diskriminasi Kualitas Pendidikan, 2) Perubahan Misi Pendidikan, 3) Memperburuk SDM dan cita masa depan, 4) Muncul rantai kemiskinan, 5) Timbul gaya hidup.

Diskriminasi Kualitas Pendidikan privatisasi pendidikan artinya dapat menimbulkan pemisahan antara para ekonomi kuat dan lemah. Lembaga pendidikan berekonomi kuat akan menjadi unggulan, sedangkan ekonomi lemah menjadi lembaga kurang vitamin. Maka yang berekonomi kuat akan mudah memperoleh pendidikan, sedangkan ekomomi lemah hanya pendidikan seadanya. Dengan adanya pemisahan ekonomi kuat dan lemah maka terjadi pelebelan sosial bahwa lembaga pendidikan yang memiliki nama (milik kelas sosial tinggi), lembaga pendidikan sederhana (milik kelas sosial bawah). Masyarakat sederhana berusaha mengecap pendidikan, tetapi harus menerima kenyataan bahwa dirinya anggota kelas bawah. Selain itu juga menimbulkan rasa keputusasaan kaum ekonomi lemah yang berdampak pada pengangguran, kriminalitas, anak jalanan, dan lainnya.

Perubahan Misi Pendidikan, artinya para pendidik bukan lagi bersifat mentalitas pendidik tetapi sudah mentalitas berdagang. "Budaya akademik" menjadi "budaya komersil" sehingga tujuan pendidikan mencerdaskan masyarakat sudah tidak ada lagi. Para pendidik telah berlomba mengumpulkan kredit koin (dollar) bukan lagi kredit point (ilmu pengetahuan).

Memperburuk SDM dan cita masa depan, artinya Adanya dorongan dari kapitalis untuk merekrut siswa dari kelas atas walaupun memiliki kemampuan yang kurang. Maka mobilitas sosial vertikal hanya untuk ekonomi kuat meskipun intelektual masih diragukan. Inilah yang dapat merusak kepemimpinan masa depan, sedangkan kaum ekonomi lemah 
yang berprestasi tidak dapat melanjutkan pendidikan.

Muncul rantai kemiskinan, karena ekonomi lemah maka tidak mendapat pendidikan. Tidak dapat pendidikan maka pekerjaan tidak ada, sehingga menjadi miskin demikian selanjutnya. Dalam kemiskinan ini komersialisasi pendidikan dapat menjadi pelanggengan "proverty trap” (jebakan kemiskinan). Dan timbul gaya hidup, akibatanya para peserta didik dari ekonomi kelas atas berpenampilan mewah, dan berbarang mewah semasa pendidikan.

Dari gambaran di atas, banya lembaga pendidikan berlomba dengan tujuan sebagai media bisnis (misi ekonomi). Lembaga pendidikan mengadakan promosi besaran, dan menawarkan terobosan seperti mudah memeperoleh pekerjaan/menjanjikan masa depan. Dengan menawarkan terobosan inilah kesempatan/cara lembaga pendidikan untuk mendapat imbalan uang yang tidak sedikit jumlahnya. Pandangan ini menjadi sumber ketimpangan sehingga terdapat pandangan bahwa para ekonomi kelas atas/tinggi yang memiliki potensi/kualitas

Menurut Marx pendidikan adalah sebagai bagian dari kehidupan masyarakat yang memiliki peran penting dalam mengembangkan SDM untuk mencapai kecakapan hidup serta sebagai media sosialisasi dalam masyarakat. Selain itu, peran pendidikan memiliki keterkaitan dengan bidang ekonomi, bahkan menjadi faktor yang tidak dapat dipisahkan untuk mencapai pendidikan yang berkualitas. Fenomena ini dapat menimbulkan komersialisasi pendidikan berbagai opini pro kontra pada masyarakat. Masyarakat melontarkan dengan berbagai tulisan dimedia massa yang salah satu hal memprihatinkan bidang pendidikan Indonesia. Bidang pendidikan merupakan bidang yang fundamental pada suatu negara dan menentukan arah serta kualitas suatu negara

Berdasarkan fakta, banyak lembaga pendidikan memiliki status yang kurang jelas namun dapat berkembang terutama di kota besar, bahkan kemungkinan dapat menuju kota kecil. Lembaga pendidikan juga menawarkan program pendidikan untuk mendapat gelar tanpa ada proses akademik. Lembaga pendidikan lebih mementingkan ekonomi daripada kualitas pendidikan yang dapat merusak tujuan dan idealisme pendidikan. Fenomena dan fakta ini merupakan salah satu masalah bidang pendidikan yang lambat laun dapat menumbuh kembangkan budaya kapitalis atau ideologi neoliberalisme dengan modus komersialisasi pendidikan. Maka dari itu inilah yang mengakibatkan menurunnya kualitas mutu pendidikan dan merusak budaya bangsa tanpa menghiraukan nilai-nilai moral bangsa

Dengan munculnya komersialisasi pendidikan adalah akibat kurangnya perhatian dan tanggung jawab pemerintah untuk mengkoordinasi bidang pendidikan seperti mencabut subsidi pembiayaan terutama pada perguruan tinggi dan pemberian hak otonom dengan status BHMN pada perguruan tinggi. Para kapitalis menjadikan dunia pendidikan salah satu unsur utama untuk membuka lembaga pendidikan dengan tujuan mendapat keuntungan ekonomi dan tidak lagi mencerdaskan kehidupan bangsa seperti tertera pada UUD 1945. Bahkan dengan APBN sebesar 20\% tidak dapat mencegah maraknya komersialisasi pendidikan. Maka sebaiknya prinsip nirlaba dapat diterapkan dalam dunia pendidikan. Artinya tujuan/prinsip utama tidak mencari keuntungan tetapi meningkatkan kualitas/mutu pelayanan pendidikan.

Maka dari itu solusi untuk mencegah komersialisasi pendidikan adalah, pertama, pemerintah melalui BPK dan non pemerintah melalui LSM melakukan pemeriksaan transaksi keuangan secara rutin terhadap semua lembaga pendidikan baik swasta atau negeri. Dalam non pemerintah diharapkan mampu bersikap independen dari pihak manapun agar tidak terjadi penyimpangan. Pihak ini harus berkoordinasi dengan departemen 
pendidikan untuk mencapai tujuan. Pihak ini juga mampu dan jujur melaporkan hal yang terjadi serta berhak melakukan evaluasi terkait kebijakan pemerintah dibidang pendidikan. Seperti penggunaan dan BOS dan lembaga pendidikan dengan status RSBI.

Kedua, penarikan uang yang dilakukan terhadap peserta didik (siswa) harus menyampaikan laporan secara terperinci dan jelas. Ini salah satu cara kurang baik dalam bidang keuangan. Dan ketiga adalah pemberian bea siswa kepada berprestasi agar bagi yang tidak mampu tetap dapat melanjutkan pendidikan.

Pada kondisi masyarakat saat ini yang terus mengalami perkembangan teknologi ternyata sangat mempengaruhi terhadap gaya hidup masyaarakat. Bahkan perubahan terus terjadi secara otomatis dalam berbagai kehidupan seperti ekonomi, budaya, politik, dan lainnya. Dibalik semua ini ternyata bidang pendidikan sudah menjalani gaya hidup. Artinya pendidikan bukan lagi bersifat potensi/mutu tetapi sudah suatu bentuk gaya hidup (life style)

Para siswa sudah saling berhubungan, bersosialisasi dengan lingkungan dan komunitasnya. Bahkan telah bergerak dengan mobilitas yang tinggi. Namun yang paling unik gaya hidup telah terjadi didunia pendidikan ditengah menjalani pendidikan. Tanpa memikirkan peran mendasar lembaga pendidikan, dan aktivitas pendidikan. Telah menganggap pola pendidikan ini telah menjadi suatu gaya hidup. Maka perubahan gaya hidup mempengaruhi pola pikir. Dalam arti pendidikan dianggap hanya untuk gaya-gayaan, bersifat keren, bergengsi ditengah masyarakat. Bersifat ikut-ikutan melihat orang lain menjalani pendidikan maka memaksakan diri menjalani pendidikan

Pendidikan dan gaya hidup bukan untuk mengeyam pendidikan, bukan untukmeningkatkan SDM (sumber daya manusia), tetapi ajang memperlihatkan status dan kekayaan. Dengan kata lain hanya untuk menunjukkan kebolehan.
Artinya dengan menjalani pendidikan dapat menunjukkan status (siapa saya). Dengan tujuan agar diketahui, disenangi, bahkan dipuji masyarakat. Namun bukan untuk menuntut ilmu, dan menambah SDM, hanya untuk status sosial ditengah masyarakat. Dalam bidang kekayaan juga demikian. Menjalani pendidikan hanya untuk menunjukkan keadaan ekonomi, bahwasannya seseorang memiliki tingkat ekonomi tinggi. Maka pengaruh status dan kekayan merupakan ajang/kesempatan untuk memperoleh pendidikan yang walaupun hanya untuk gaya hidup. Gaya hidup kosumtif bidang pendidikan sudah terlihat diberbagai penjuru kota. Para peserta didik (siswa) sudah tidak lagi mengadakan kontak perkuliahan, hanya menggunakan internet (on line) perkuliahan dapat berlangsung. Tanpa mengadakan proses akademik, dan proses pembelajaran pendidikan dapat berlangsung. Tanpa mengadakan tatap muka pendidikan dapat berlangsung

Dalam prakteknya, gaya hidup bidang pendidikan terlihat begitu banyak peserta didik (siswa) berselancar dituan google daripada bertanya kepada pendidik/guru. Para peserta didik lebih baik mengerjakan tugas dengan gadget dari pada berdiskusi dengan sesama. Ini menyebabkan terjadinya kesenjangan dalam dunia pendidikan sehingga semakin jelas bahwasannya dalam menjalani pendidikan hanya untuk gaya hidup

Proses menjalani pendidikan para pendidik mengenakan mobil mewah, berpenampilan mewah, dan menggunakan alat mewah. Apakah proses pendidikan hal ini sangat dibutuhkan? Inilah yang dikatakan gaya hidup dalam menjalani proses pendidikan. Terlebih lagi jika untuk mengenakan baju toga, sudah menjadi gaya hidup yang sangat didambakan. Bukan untuk dipungkuri bahwa cita-cita memang demikian, hanya yang timbul adalah para peserta didik (siswa) menjadi sebagai (agen of change) agen perubahan gaya hidup serba mudah dan mewah. Selain itu para peserta didik (agen of 
social) menjadi komersil sosial untuk mengerjakan gaya-gaya hidup kekinian

Dari gambaran diatas maka senada menurut Chanet (dalam Subandy 1997) yaitu industri gaya hidup, berpenampilan diri (tubuh/body/self) menarik dan indah adalah sesuatu menjadi gaya hidup, membuat agar diperhatikan orang. Seperti ada bahasa slogan "bergayalah maka kamu akan ada". Gaya hidup sudah merupakan industri penampilan. Gaya hidup juga sudah merupakan iklan/promosi hidup. Berpenampilan hidup dapat sebuah promosi pameran terhadap masyarakat. Promosi mempresentasikan gaya hidup dengan menanamkan secara halus (subtle) arti pentingnya citra diri untuk tampil ditengah masyarakat (publik). Dengan sendirinya promosi perlahan tapi pasti mempengaruhi pilihan ctra rasa yang menarik. Dengan tujuan agar penampilan gaya hidup disenangi masyarakat, dan menimbulkan/membentuk budaya citra (image culture) serta budaya citra rasa (taste culture)

\section{SIMPULAN}

Dari uraian tulisan ini tentang komersialisasi pendidikan dan gaya hidup maka komersialisasi pendidikan telah menjadi barang bisnis, barang komoditas, barang dagangan. Pendidikan telah menjadi sesuatu yang mudah diperoleh, mudah dicapai tidak harus melalui proses pembelajaran dan akademik. Dengan keadaan demikian semakin jelas bahwa pendidikan telah bersifat komersil. Akan tetapi ada suatu hal yang unik yaitu tanpa mengadakan interaksi langsung atau tidak langsung pendidikan dapat berakhir (tamat pendidikan). Komersialisasi pendidikan tidak mengutamakan potensi/kualitas tetapi hanya berorientasi bersifat ekonomi. Maka yang dinamakan hak dan kewajiban sudah tidak ada lagi

\section{DAFTAR PUSTAKA}

Depdiknas. (2003). Undang-Undang RI Nomar 20 Tahun 2003 Tentang Sistem Pendidikan Nasional
Hartini, D., (2011). Probelamtika Pendidikan diera Globelisasi

Hasbullah, (2005). Dasar-Dasar Ilmu Pendidikan, Banjarmasin : Rajawali Press

Ibrahim, I.S., (1997). Lifestyle Ecstasy (Kebudayaan Pop Dalam Masyarakat Komoditas Indonesia. Yogyakarta. Jalasutra

Kartono, (2002). Menebus Pendidikan yang Tergadai Catatan Reflektif Seorang Guru. Yogyakarta : Galang Press

Kotler P., dan Gary A. (2012), Prinsip-Prinsip Pemasaran. Bandung. Erlangga

Marimba, D. A. (1962). Pengantar Filsafat Pendidikan Islam. Bandung. Al-Ma'arif

Pasaribu, P., (2017). Peranan Partai Politik dalam Melaksanakan Pendidikan Politik. JPPUMA: Jurnal Ilmu Pemerintahan dan Sosial Politik, 5 (1): 51-59

Pinem, $M$ (2016). Pengaruh Pendidikan dan Status Sosial Ekonomi Kepala Keluarga bagi Kesehatan Lingkungan Masyarakat, Jurnal Ilmu Pemerintahan dan Sosial Politik, 4 (1): 97-105.

Purba, I.A., dan Ponirin, (2013). Perkembangan Amal Usaha Organisasi Muhammadiyah di Bidang Pendidikan dan Kesehatan, Jurnal Ilmu Pemerintahan dan Sosial Politik, 1 (2): 112-122.

Ritzer, G. (2002). Ketika Kapitalisme Berjingkrang. Yogyakarta. Pustaka Pelajar

Siregar, N.S.S., (2013), Persepsi Orang Tua terhadap Pentingnya Pendidikan bagi Anak, Jurnal Ilmu Pemerintahan dan Sosial Politik, 1 (1): 11-27.

Siregar, N.S.S., (2016). Tingkat Kesadaran Masyarakat Nelayan terhadap Pendidikan Anak, Jurnal Ilmu Pemerintahan dan Sosial Politik, 4 (1): 110.

Sitanggang, M.D., dan Suadi H., (2014). Persepsi Masyarakat Terhadap Kinerja Camat Dalam Meningkatkan Mutu Pendidikan, Jurnal Ilmu Pemerintahan dan Sosial Politik, 2 (1): 58-77.

Suharyanto, A., (2013). Peranan Pendidikan Kewarganegaraan Dalam Membina Sikap Toleransi Antar Siswa, Jurnal Ilmu Pemerintahan dan Sosial Politik, 2 (1): 192-203

(2015). Pendidikan dan Proses Pembudayaan dalam Keluarga, Jurnal Pendidikan Ilmu-Ilmu Sosial, 7 (2) (2015): 162-165. 
Murni Eva Marlina Rumapea, Pendidikan Komersial dan Gaya Hidup

Wahono, F. (2001). Kapitalisme Pendidikan Antara Kompetisi dan Keadilan. Penerbit INSIST Press
Wibowo, A. (2008). Malpraktik Pendidikan. Yogyakarta. Genta Press. 